\title{
実践研究
}

\section{学童保育クラブにおける統合保育の現状と問題点 困難事例の保育の進行過程の分析}

\author{
西 本 絹 子*・浜谷 直 人** $^{* *}$
}

学童保育クラブにおける障害児統合保育の巡回相談事例から、17の事例を保育の進行がス ムースでないと判断した。第一にそれぞれの事例について、指導員（保育者）の「問題の気 づき・意識化 $\rightarrow$ 調整 $\rightarrow$ 統合」という枠組みからその保育の進行状況を捉え、5段階のレベル分 けを行い、保育の実態を分析した。第二にそれぞれの事例において保育の進行を妨げている と思われる問題の要因を挙げ、統合保育の発展について考察した。

キー・ワード：学童保育クラブ 総合保育 巡回相談 保育の進行状況

\section{I. 問 題}

近年、学童保育にも障害児が受け入れられ、統合保 育が広く行われるようになってきている。自治体に よっては早いところでは 1970 年代の末から 80 年代の 始めには条例化・制度化されており（神山・森川・小 野, 19894)；伊藤，1992 ${ }^{3}$ )、保育園・幼稚園（以下，「園」 と略）における統合保育の歴史と比べると、短いとこ ろでは数年の差しかない（例えば東京都の先進的なあ る区では 4 年)。しかし、その実績や理論的研究の積み 重ねは、園のそれに比べると比較にならないほど少な いと言える。そもそも全国的に学童保育の制度そのも のが末成熟な現状もあり、統合保育に関しては「どの ような特徵・問題点を持つのかという点も不明確なま ま、試行錯誤で日々の保育が営まれているように思わ れる」（藤崎・西本・浜谷・古屋・ 户田・吉川・村田, $\left.1992^{11}\right)$ 。しかし、学童保育の国としての制度化への情 勢、園や学校教育におけるインテグレーションがより 一般化され普及されつつある現代の流れにあっては、 学童保育におけるインテグレーションの分析的検討が 重要な課題である。

ところで筆者らは、ある自治体において障害児学童 保育巡回相談望ををおこなっている。そこで筆者らは、 学童保育における統合保育を分析する第一の試みとし て、学童保育クラブの指導員から巡回相談員 ${ }^{2}$ に出さ

*法政大学

**東京都立大学
れた主訴涪 3 をまとめ、自閉傾向坚と軽・中度の精神発 達遅滞児（知恵遅れ）という障害内容別に、保育上の 問題を特徵づける報告を行った（藤崎, 1992 ${ }^{1)}$; 西本・ 藤崎・浜谷・古屋・戸田・吉川・村田, $\left.1992^{6)}\right)$ 。そこで は、指導員の悩みは、障害児の障害に原因を州しても その解決につながりにくく、他のさまざまな要因を含 めて考える必要があることを示唆した。

ところがその要因について、指導員が問題意識を 持っていないときに、巡回相談員が分析した問題要因 を指導員に指摘しても、指導員は実感を持って指摘を 受けとめることができない。このため相談員が問題点 を指摘するだけでは保育の改善へと保育が進行してい かない。そこで、ここでは、宮武 $\left(1990^{5}\right)$ の提唱にな らい、指導員の現在の保育の営みをまず認めた上で、 それを不断に修正していく手続きとして保育を考えて みる。そうすると保育は Table 1 のような過程(浜谷・ 西本・木原・村田・常田・藤崎 - 古屋 - 吉川 - 田口・ 鈴木, 19942)）が進行していくものとみなすことができ る。

つまり、そのときの保育の目標などに照らして、保 育の現状に問題を感じ、それを意識化、整理して何ら かの調整（子供の能力を高めるだけでなく, 周囲の許 容性を高めることも含む) を行い、子供の発達をより 実現する方向で保育が統合されていくという過程であ る。

本研究では、学童保育の統合保育に見られる問題を、 このような枠組みから整理して現状と課題を考察しよ 
Table 1 保育の進行状況

$$
\text { 問題への気づき・意識化 } \rightarrow \text { 調整 } \rightarrow \text { 統合 }
$$

Table 2 巡回相談の概要

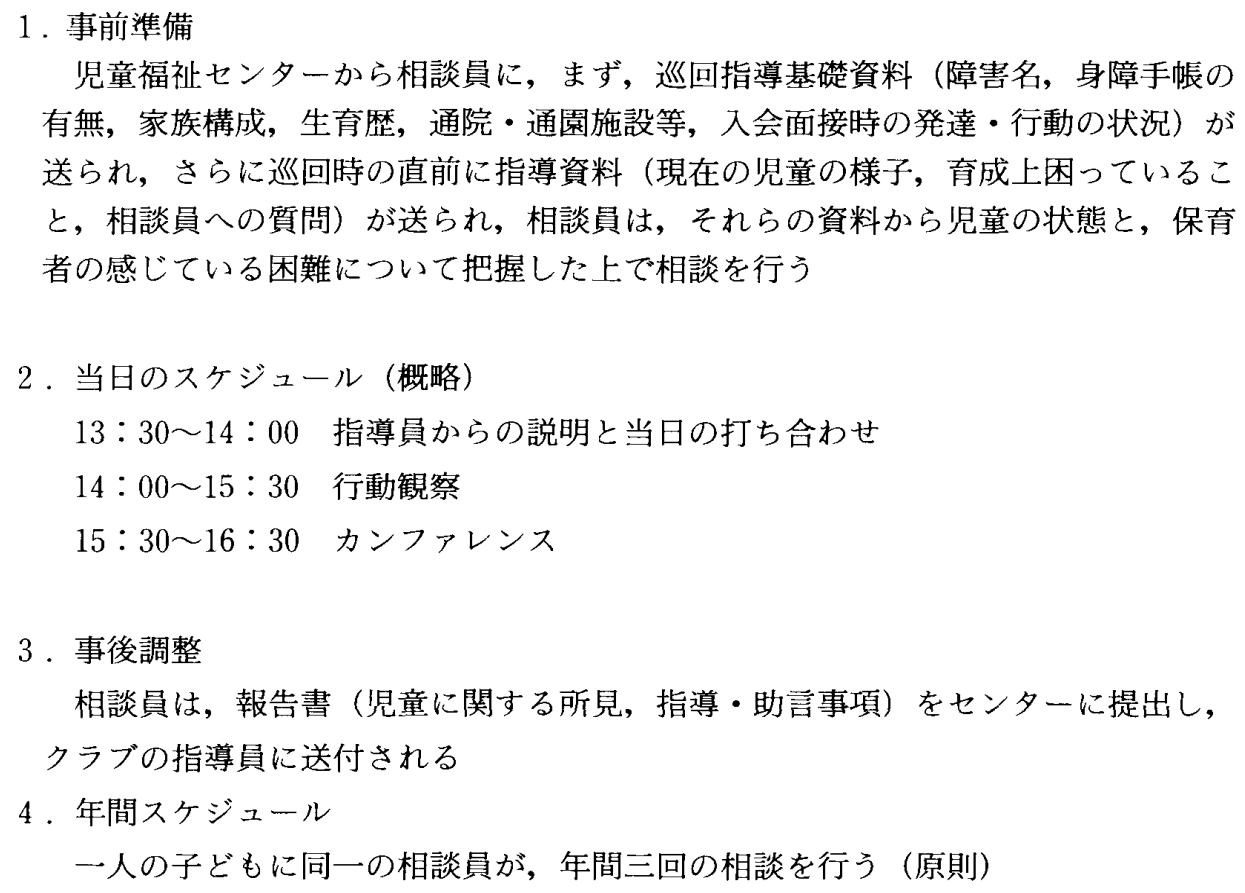

うとする。

なお、筆者らが行っている障害児巡回相談の概要は 以下の通りである。

\section{X区における障害児学童保育}

学童保育クラブ定員 45～50 名に正規職員（指導員） 2 名が配置される。審査会を通して障害児の入クラブ が許可された場合、障害児 2 名につき 1 名（重い障害 の場合は 1 名につき 1 名）の非常勤職員が週に 5 日、 クラブに加配される。

\section{X 区における障害児巡回相談}

筆者らを含む計 8 名の相談員グルーブが、区内の学 童クラブの半数の障害児巡回相談を 1991 年の巡回相 談開始時より担当している。現場では各ケースに 1 名 の相談員と区の職員とで相談活動を行う。巡回相談は Table 2 の要領で行われている。

\section{II. 方 法}

筆者らは1991 年から 1993 年にかけて障害㚾巡回相 談を計 24 事例担当した。そのなかで、各相談員が保育 がスムースに行われていないと判断した事例が 17 あった。17 事例中 11 を筆者らが担当し、そのほかは各
相談員が 1 事例から 4 事例ずつ担当した。それぞれの 事例について、各相談員が指導員の主訴、児の生育歴、 児の保育歴、児の発達像、保育観察結果、指導員への 助言事項を報告し、相談員全員で事例ごとの保育の進 行状況の検討を行った。

検討は、Table 1 に示した宮武の提唱する枠組みに ならい、次のように進めた。第一に指導員に問題意識 があるかどうか、ある場合はどのような問題意識であ るか。第二に問題意識にもとづいてどのような調整が 行われているか。すなわち、児への働きかけ・児をめ ぐる周囲の調整（他児へのはたらきかけや規則の改変, 施設の改善など）はどのようになされているか。第三 に調整が児の発達を実現する方向に統合されようとし ているかどうか。

検討の結果、17の事例の保育の進行状況についてレ ベルが分けられた。また、通行を妨げていると思われ る保育の背景にある問題要因を抽出し整理した。

\section{III 。結果と考察}

\section{1. 保育の進行状況のレベル分けからみた実態}

進行状況のレベルが低いものから順番に以下のよう 
に(1)から(5)の 5 つのレベルに分けられた。

（1）「問題への気づき・意識化」における進行の滞り。 指導員が現状の問題に気づいていない。

(1)-1；児が目立つような問題行動もなく安全に過ご しているので問題がないと考えられているが、実際は 他児との関わりもなく放置されている。

事例(1) 精神発達遅滞 3 年生男子：ひたすら一人 で楽しそうにごっこ遊びを繰り返して過ごす。いつも 同じパターンなので、他児達は全く相手にしない。問 題行動もなく柔和な性格の児なので、発達の弱さをき ちんと捉えられないまま放置が続き「楽しそうに遊ん でいるから問題がない」とされている。

事例(2) 精神発達遅滞 (ダウン症候群) 5 年生男子： 当該児は学校で放任されており、いじめられてもいる。 親と学校の関係も悪い。そんな中でクラブに児を受け 入れることが親の支えになり、それがクラブの主要な 役割であると指導員は考える。クラブにはなじんでい る様子だが、他児との関わりは殆どなく、目の前の他 児達の名前も全くわからない。大人との会話は時々成 立し、集団遊びに誘われると少し参加するが、すぐに 外れ架空と現実を織りまぜた独り言をしゃべって過ご 寸。

〈背景にある問題〉児の発達を促すという指導態度が 指導員にない。またはクラブは親の就労の保障の上で 乱童を安全に保護するためのもので、意図的な保育を 行う場とは一般的には考えられておらず、障害児に対 してもそのような役割意識が強いためと思われる。ま た(2)は児にとって生活の核となる学校との関係が安定 しない場合、指導員もそれにとらわれ保育の問題の発 見に至りにくいという原因も指摘できよう。

(1)-2；指導員は問題がないと考えているのではない が、児の一側面 (何かが上手, または下手) だけにとら われ、全体の発達像がわからず、そのために問題に気 ブくことが出来ない。

事例(3) 自閉的傾向 2 年生男子：「特定の遊び（折 り紙やビーズ）にかなり高い能力を発揮する。それに 比べて他のこと（場面の切り替えや，他児との遊び，集 団参加）が出来ないのがおかしい」と指導員は訴える。 実際は、特定の遊びを一人黙々と、達成感や他者との 共感もなくやり続けているだけである。このためおや つを一緒に食べられないという問題が解決した後は放 置状態になっている。

事例(4) 自閉傾向 6 年生男子：運動遊びを嫌がる こともあり、粘土や折り紙がとても上手なのでずっと そればかりして（させて）、一人で過ごしている。気に
入った女児に抱きついたり後ろから押したりといった 困った行動もある。社会的ルールや他児との付き合い かたを育てること、下校の早い日の運動遊びの取り組 みなど、問題の意識化が必要だった。

〈背景にある問題〉(1)-1 の指導観に加えて、「できるか できないか」から子供像を捉え、しかもできないのは 児の側に原因があると考えたり、できることだけして いればよい、楽しんでいればよいとされたりし、指導 員の子供像の捉えなおしが必要である。

（2）「問題の気づき・意識化から調整」間における進 行の帯り。指導員は問題には気づいているが調整に つながるはっきりした問題の意識化（明確化）が出 来ない。子供の発達や障害の見方が分からないため、 どんな㗢きかけがよいのか、保育していてどういう 成果があるのかが指導員にわからない。

事例(5) 精神発達遅滞 (ダウン症候群) 2 年男子：児 は何を見ているのかも判然としないし、手が触れた物 をいじるだけである。人との関係も母親でさえも区別 しているのかどうか推測しがたい。指導員は児の発達 レベルや行動の理解の仕方がわからず、クラブにおい てどんなことを指導目標にすればよいのかも見当がつ かない。当面の問題として不意に他児へのかみつき、 突き飛ばし、異食（石鹼など食べる）などをするので、 つききりで本児と他児の安全を守ることに追われてい る。

事例(6) 脳性麻痺 精神発達遅滞 4 年生女子：児 は言葉の理解や場面の理解はほとんどない。ひたすら バドミントンをやりたがり、相手は誰かれ構わない。 指導員が根気よくつきあっているが、このままでよい のか、どうしたらよいのか悩んでいる。一方、児が他 の物に興味を持って触ろうとしたり、自分も欲しいと いって要求すると、ルールに反すると禁止したり、他 児と同じレベルの課題を課したりと、全体として扱い が全く分からない。

事例(7) 自閉傾向 1 年生男子：乳児後半期の発達 レベルの児で、指導員は毎日熱心に保育に当たってい るが、保育目標は“安全に過ごすこと”であり、この 先どれだけ発達の見通しがあるのかわからない、とい う。おんぶやだっこの要求が出てきたがそれだけ続け ていてよいのだろうか、と悩んでいる。

事例8 精神発達遅滞 3 年生男子：「全体の集ま りの時静かに出来ない。分かっているのか、いないの か。模倣力や優れた運動能力を使って他児との関わり を引き出したいがどうしたらよいか」という主訴で、 指導員は根気よく付き添っている。児は乳児前期のコ 
ミュニケーションの力も未発達であり、物に対する関 わりも殆ど見られず、自己刺激で楽しんだり行動をコ ントロールしている。発達像がまったく把握されてい ない状態である。

事例(9) 精神発達遅滞 2 年生男子：指導員は「児 が何が得意でどんな遊びが好きなのか、どんな取り組 みを用意したらよいのか分からない」という。児は指 導員が考えていた発達レベルより、はるかに多くの弱 さを持っており、それを細かくきちんと理解すること が必要な状態である。

事例(10) 自閉傾向 1 年生男子：保育への意欲は高 くたいへん練やかな保育がなされていた。しかし指導 員は「障害の基本的知識がなく、これでいいのかどう か、障害の見方やどんな動きかけがよいのかわからな い」と悩んでいる。

〈背景にある問題〉障害の重さの程度に関わらず、発 達や障害に関する基本的な見方、知識が指導員に不十 分である。また、さらに障害の重い場合は、大人との 確かな一対一関係の形成が保育上重要と考えられ、生 活行動上も指導員がつききりにならざるを得ないた め、保育体制の問題と指導員の精神的負担の問題が生 じる。クラブに通う意義、発達の見通しや目標をどこ に置くのかなどの問題も、より話し合っていく必要が ある。

（3）「調整」に入ろうとする時点に扔ける進行の滞り。 問題は明確化されているが、よい保育方法がわから ないので調整できない。

事例(11) 脳性麻痺 1 年生女子：知的な遅れはない が、移動の不自由さ（伝い歩きかよつばい）もあり、 他児との関わりがなかなかできず、コミュニケーショ ンの力は育っていない。指導員はその点に問題を感じ ているが、主に親の関わりかたのまずさや自己本意な 性格のためと考えていたためもあり、クラブのなかで の適切な保育方法がよくわからない。また広くて 4 階 にも渡る複雑なクラブの建物に、子どもたちがそれぞ れ異なる時間に帰ってきて散らばり自由に遊んでいる という事情もあり、移動が不自由で他児との関わりや 遊びに制限が多い児の、気になるコミュニケーション のしかたを変えていく保育方法は難しい点が多い。

事例(12) 自閉傾向 1 年生男子：乱暴でコミュニ ケーションが取りづらい児であるが、工作の能力は高 く時々面白いことも言う。そういった面を活かして他 児との関係作りをしたいと指導員は考えていたが、満 足そうに工作している時間を無理に壊してどの程度、 いかに他児との関係作りに誘ったらよいか、悩んでい
る。

〈背景にある問題〉クラブの特性の問題。園と異なり、 集団活動や指導者の意図的な活動はクラブでは「おや つの時間」以外は少ない。子どもたちが好きな場所で 好きなことをしているのが一般的であり、通ってくる 時間も曜日も不規則である。また、クラブは、子ども にとって、放課後自由に過ごしてほっとする場という 性格もある。そのような事情をふまえての、学齢期の 児の発達や仲間関係を促すための統合保育方法の実践 の蓄積がなく、試行錯誤の状態である。

(4)「調整」における進行の滞り。指導員は調整をし ようとしているが、クラブの可能な調整範囲を超え る。

(4)-1：クラブ以外の場（家庭や学校）での不適応と いう問題があり、その悪影響がクラブでの児の行動と なって出現するが、その問題をクラブは解決できない。

事例(13) 自閉傾向 2 年生男子：飛び出し、かみつ きなどの攻撃的行動が多発し、一瞬たりとも目が離せ ない。パニック時は他児達も恐慌を引き起こすし、保 育体制上限界にきている。背景に心障学級での厳しい 指導があり、児はその荒れを持ち込んでいた。指導員 は懸命に対処しているが、クラブだけでは問題解決に なりにくく、責護学校転校を親に勧めている。

〈背景にある問題〉学校生活の安定が保障されないと クラブの生活の安定は難しい。クラブの保育体制の限 界。

(4)-2：身体も大きい児の危険な行動・乱暴な行動に、 児と他児双方の安全保護をはからなければならないこ とに指導員が疲労困䣏している。

事例(14) 自閉傾向 3 年男子：児の発達自体は順調 で保育も熱心だが、他児への乱暴を防ぎ安全を保障し なければならないので、そのことに指導員は常に強い ストレスがある。

〈背景にある問題〉保育体制の限界。身体も大きい学 童であり、安全管理の面での問題は時としてクラブの 調整可能な線を超える。

（5）「調整から統合」における進行の滞り。指導員は 問題意識を持って調整しているつもりだが、児の発 達を実現する保育に統合されない。

(5)-1：指導態度から生じる保育方法の問題

事例(15) 自閉傾向 2 年生男子：指導員は「生活面 ではスムースだが、他児と差があり遊ばない。思うよ うにならない時どうルールをわからせていくか。他児 と規則の差はつけられない」という。児の発達は順調 で、一年生程度の社会的ルールや遊びのルールも知的 
Table 3 保育の進行状況の背景にある問題要因

\begin{tabular}{|c|c|c|c|c|c|c|c|c|c|c|c|c|c|c|c|c|c|c|c|}
\hline \multirow{4}{*}{\multicolumn{3}{|c|}{\begin{tabular}{|l} 
進行状況のレベル \\
問題の諸要因 \\
事(例 ${ }^{11}$
\end{tabular}}} & \multicolumn{4}{|c|}{ (1) } & \multirow{2}{*}{\multicolumn{6}{|c|}{ (2) }} & \multirow{2}{*}{\multicolumn{2}{|c|}{ (3) }} & \multicolumn{2}{|c|}{ (4) } & \multicolumn{3}{|c|}{ (5) } \\
\hline & & & \multicolumn{2}{|c|}{ (1)-1 } & \multicolumn{2}{|c|}{ (1) -2} & & & & & & & & & \multicolumn{2}{|c|}{ (4)-1 $\mid(4)-2$} & \multirow{3}{*}{$\begin{array}{l}(5)-1 \\
\text { (15) } \\
\text { 軽 }\end{array}$} & \multicolumn{2}{|c|}{ (5)-2 } \\
\hline & & & (1) & (2) & (3) & (4) & \multirow{2}{*}{$\begin{array}{l}(5) \\
\text { 重 }\end{array}$} & \multirow{2}{*}{$\begin{array}{l}(6) \\
\text { 重 }\end{array}$} & \multirow{2}{*}{$\begin{array}{l}(7) \\
\text { 重 }\end{array}$} & \multirow{2}{*}{$\begin{array}{l}8 \\
\text { 重 }\end{array}$} & \multirow{2}{*}{$\begin{array}{l}(9) \\
\text { 軽 }\end{array}$} & \multirow{2}{*}{$\begin{array}{l}10 \\
\text { 軽 }\end{array}$} & \multirow{2}{*}{$\begin{array}{l}\text { (11) } \\
\text { 軽 }\end{array}$} & \multirow{2}{*}{$\begin{array}{l}\text { (12) } \\
\text { 軽 }\end{array}$} & \multirow{2}{*}{$\begin{array}{l}(13) \\
\text { 重 }\end{array}$} & \multirow{2}{*}{ 苜 } & & \multirow{2}{*}{$\begin{array}{l}\text { (16) } \\
\text { 軽 }\end{array}$} & \multirow{2}{*}{$\begin{array}{l}171) \\
\text { 軽 }\end{array}$} \\
\hline & & & 軽 & 軽 & 軽 & 重 & & & & & & & & & & & & & \\
\hline \multirow{9}{*}{$\begin{array}{l}\text { 指 } \\
\text { 導 } \\
\text { 員 } \\
\text { 側 } \\
\text { の } \\
\text { 要 } \\
\text { 因 }\end{array}$} & \multirow{4}{*}{$\begin{array}{l}\text { 指 } \\
\text { 導 } \\
\text { 態 } \\
\text { 度 }\end{array}$} & $\begin{array}{l}\text { 生活面で困らず楽しく遊んでい } \\
\text { ればよいとする }\end{array}$ & $\bullet$ & $\bullet$ & 0 & - & & & & & & & & & & & & & \\
\hline & & $\begin{array}{l}\text { 集団のルールや整然としている } \\
\text { ことを重視する }\end{array}$ & & & 0 & & & & & & & & & & & & ○ & & \\
\hline & & 問題行動に懸命に対処する2) & & & & & 0 & 0 & 0 & 0 & & & & & 0 & 0 & & & 0 \\
\hline & & $\begin{array}{l}\text { 児の発達の実現のためなんらか } \\
\text { の意図的な働きかけをしたいと } \\
\text { する゙2 }\end{array}$ & & & & & & & 0 & 0 & 0 & 0 & & 0 & & 0 & & 0 & \\
\hline & \multirow{3}{*}{$\begin{array}{l}\eta \\
\text { 亏 } \\
\text { ブ } \\
\text { の } \\
\text { 役 } \\
\text { 割 } \\
\text { 観 }\end{array}$} & $\begin{array}{l}\text { 親の就労の保障・児の放課後の } \\
\text { 安全や楽しく遊ぶ場所であるこ } \\
\text { とを重視する }\end{array}$ & $\bullet$ & 0 & 0 & ○ & & & & & & & & & & & & & \\
\hline & & $\begin{array}{l}\text { 集団生活の場であることを重視 } \\
\text { する }\end{array}$ & & & O & & & & & & & & & & & & 0 & & \\
\hline & & $\begin{array}{l}\text { 仲間関係や何らかの児の発達を } \\
\text { 促す場であるとを重視する2) }\end{array}$ & & & & & & & & & 0 & 0 & 0 & 0 & & & & & \\
\hline & \multirow{2}{*}{ 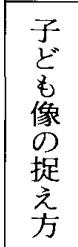 } & $\begin{array}{l}\text { 問題行動の有無や,できる・で } \\
\text { きないの側面からみるなどれる } \\
\text { 全体像が捉えきれない }\end{array}$ & & & 0 & 0 & & & & & & & & & & & & & 0 \\
\hline & & $\begin{array}{l}\text { 幼児期以前の発達段階の子ど } \\
\text { も、障害の見方がよく分からな } \\
\text { い }\end{array}$ & & & & & ○ & - & $\bullet$ & 0 & - & 0 & & & & & & 0 & - \\
\hline$\eta$ & 学标 & 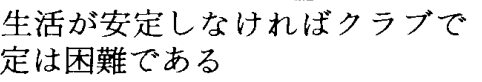 & & 0 & & & & & & & & & & & 0 & & & & \\
\hline $\begin{array}{l}\text { ラ } \\
\text { ブ } \\
\text { 品 }\end{array}$ & $\begin{array}{l}\text { 子与 } \\
\text { 独目 } \\
\text { 難 }\end{array}$ & $\begin{array}{l}\text { も達の過ごす時間や過ごしうの } \\
\text { さをふまえた統合保育の方法が } \\
\text { い }\end{array}$ & & & & & & & & & & & 0 & 0 & & & & & \\
\hline 性 & 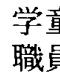 & $\begin{array}{l}40 \text { 数人に指導員 } 3 \text { 人程度という } \\
\text { 体制では困難である }\end{array}$ & & & & & & & & & & & & & 0 & - & & & \\
\hline 児 & 障 & $\begin{array}{l}\text { 発達や障害に関する知識がより } \\
\text { 不可欠をる }\end{array}$ & & & & & 0 & 0 & 0 & 0 & & & & & & & & 0 & - \\
\hline $\begin{array}{l}\text { 障 } \\
\text { 害 } \\
\text { 多 } \\
\vdots \\
\vdots\end{array}$ & $\begin{array}{l}\text { 袁 } \\
\text { 重 } \\
\text { 重 }\end{array}$ & $\begin{array}{l}\text { 指導員との一対一関係の形成を } \\
\text { こここで求められるか, 又をの } \\
\text { 負担の問題が生じる }\end{array}$ & & & & & 0 & 0 & 0 & - & & & & & & & & & 0 \\
\hline $\begin{array}{l}\text { 特 } \\
\text { 徵 } \\
\text { 至 }\end{array}$ & 合 & $\begin{array}{l}\text { 統合保育の目標設定, 保育方法 } \\
\text { の困難さが生じる }\end{array}$ & & & & & 0 & 0 & 0 & 0 & & & & & & & & & \\
\hline $\begin{array}{l}\text { け } \\
5 \\
\text { u } \\
3\end{array}$ & $\begin{array}{l}\text { 障 } \\
\text { 害 } \\
\text { 軽 }\end{array}$ & $\begin{array}{l}\text { 生活面がスムースな場合問題が } \\
\text { 紛れやすく放置につながりす } \\
\text { い }\end{array}$ & - & & - & & & & & & & & & & & & 0 & & \\
\hline $\begin{array}{l}\text { 問 } \\
\text { 題 }\end{array}$ & $\begin{array}{l}\text { 場 } \\
\text { 合 }\end{array}$ & $\begin{array}{l}\text { 仲間関係の形成に重い障害の場 } \\
\text { 合と異なる難しさが生じる }\end{array}$ & & & & & & & & & & & & & & & & & \\
\hline
\end{tabular}

(注)

1）「軽」は児の障害がどちらかといえば軽い場合,「重」はどちらかと言えば障害が重い場合であることを表す。障害が 重いとは, 養護学校に通学しているか, 心障学級に通学しているが一般的な基準からみると養護学校通学が適切と判 断される場合とした，障害が軽いとは，重い場合以外である

2 )この 3 項目は保育の進行を直接的に妨げる要因ではなく，それ自体はむしろ進行を促す要因であるが，他要因との関 連性を見るために挙げた。したがって当てはまる場合を○印で表示し，妨げる要因である○印と区別した 
には理解でき、大人の仲介次第で遊べることもある(ウ ノ，しりとり，ピンポンなど）。奇妙な点はあるものの、 やりとりは大体成立する。しかし、整然とした遊びの 形態やクラブの規則を崩したり工夫したりして本児に 合わせることはなされず、そばにいてもまるで存在し ないかのように他児達から対されている。

〈背景にある問題〉子どもは整然と行動しルールを守 ることがクラブの生活に重要であり、保育の目標であ るという指導態度が指導員にあり、それを障害児にも 当てはめようとする。また、障害児であるという意識 はあっても、社会性や自我の発達の面では配慮されず、 他児と同等な扱いをされる傾向がある。

(5)-2:児の障害の軽減に適切ではない保育が行われ ている。

事例(16) 精神発達羊滞（プラダーウイリ一症候群） 3 年生男子：指導員は発達の遅れや体重増加予防に取 り組みたいと思っているが、親の生活態度に不信感を 抱いて抢り、その悩みが強く、親への働きかけに力を 入れている。児の発達を促す適切な保育は実現されて いない。児は他児との関わりは殆どなく、指導員も児 の発達レベルを考慮しない教示をしている。

事例(17) 精神発達遅滞 (ダウン症候群) 3 年生女子： ことばの力を伸ばしたいと指導員は考えているが、児 は自傷行為やおやつをばらまくなどの問題行動を頻発 する。その行動を指導員は否定的に捉え、行動の裏側 にある児の気持ちを考えないまま、問題行動をいかに 減らすかに苦心している。

〈背景の問題〉指導員に発達や障害に関する基本的な 見方、知識が不足している。クラブでの児の障害に合つ た適切な保育方法を考えるためにケースワーカーや専 門職（ST, PT, OT，栄養士など）の指導を受けること もより積極的に考えられてよい場合がある。

\section{2. 背景にある問題の整理}

1 の保育の進行状況のレベル分けの検討において指 摘された、各事例の背景にあり進行を妨げていると思 われる問題要因を抽出し整理した。また同時に事例の 中の要因どうしの関連を見るために、直接に妨げる要 因とは思われないが、進行に間接的にマイナスの影響 があると思われるもの、進行を促していると思われる 要因も挙げ、問題の構造の特徵とした。その結果、指 導員の側の要因（指導態度・クラブの役割観・子ども 像の捉え方)、クラブの特性・性格、児の障害から特徵 づけられる要因、の 3 点にまとめられた。これを Table 3 に挙げた。もちろんこれは今回の事例に関して、保育 の進行を左右していると思われた要因の整理であり、
一般的なものではない。これにより、次のようなこと が言えよう。

1）保育の進行状況のレベルが低いほど、指導員の 側の要因が多く指摘されるが、これは Table 1 からの 定義上当然とも言える。

2 ) 指導員の態度や役割観などについて、相談員が 働きかけることは、保有を進行させるためにしばしば 重要である。しかし、指導員の態度や役割観が常に保 育の進行にとって最大の問題ではない。態度や役割観 が、保育の進行を阻害していると思われない事例 (7), (8)，(9)，(10，(111，(12)，(13，(14)，(16)）の場合、大きな原因は 子ども像の捉え方の難しさ、学童保育クラブの特性、 障害の重さに由来する保育の困難さなどにある。

3) 各要因は相互的な関係が見られる。児の障害が 軽いほど、指導員の側の問題意識の要因が保育の進行 に関わりやすく、保育全体の問題像も差異が大きく、 進行状況のレベルも 4 段階に渡っている（事例(1), (2), (3)，(9), (10)，(11)，(12)，(15)，(16，(17)。览の障害が重い場合 は問題像が似て、問題行動への対処の仕方、障害の理 解の仕方、保育目標の設定の難しさ、適切な保育を実 施することの職員体制上の難しさが、共通の問題要因 になる（事例(5), (6), (7), (8), (13), (14))。

\section{IV. 結 語}

学童保育クラブの統合保育を、保育の進行状況とい う視点から分析した。巡回相談の時点における保育の 進行状況は 5 段階にレベル分けされた。さらに、進行 を妨げている要因を抽出し整理を行った。それぞれの 事例の保育の進行状況において、進行を滞らせている 主たる要因は次の通りだった。指導員の側の問題（指 導態度・学童保育クラブの役割観・子ども像の捉えか た)、クラブという場の特性（子供にとって生活の核と なる学校を終えた後の時間を過ごす場であること・保 育時間の短さ，不規則さ・保育体制，物理的な条件の制 約)、児の障害内容からの問題、の 3 点である。

したがって、個々の事例に応じて、何が保育の進行 を妨げているのかを特徵化し、その問題に対して適切 な解決方法を考えることが、保育の進行につながり、 子どもの発達の実現に統合されていくと筆者らは考え る。

今後は、保育の進行を妨げている問題要因をそれぞ れもっと詳しく検討する必要がある。園における統合 保育との比較も重要である。

筆者らは保育園における統合保育が先進的なある自 
治体 $Z$ 区に扔いて、障害児保育巡回相談を 10 数年間 行ってきている。そこで園の場合と比べると、学童保 育の統合保育の場合、保育者の問題意識に㗢きかける 必要がある事例がたいへん多いという印象を持ってい る。しかし、それはたんに統合保育の蓄積の浅さ、保 育者の経験の少なさ、条件の不十分さなどの原因に由 来し、園も含めた統合保育全体の問題のひとつとして 位置づけられるものであるのか、あるいは学童保育固 有の困難点があるのか、厳密な比較検討は今後の課題 である。

また、今回は保育がスムースに進行していないと判 断された巡回相談時点における進行状況の分析を行っ たが、今後は、指導員の調整と相談員が行った相談活 動とを絡めた、保育の進行過程の綻断的な分析を行う ことが必要であると考える。

\section{謝 辞}

本研究をまとめるにあたり、共に巡回相談活動を行 い、また協力や助言をいただきました東京発達研究会 のメンバーである藤崎春代氏、村田叮子氏、吉川はる 奈氏、古屋喜美代氏、田口久美子氏、鈴木さゆり氏、 木原久美子氏、常田秀子氏に深く感謝いたします。

注

注 1 : 巡回相談という名称は一般的に用いられる用語 ではないが、浜谷ら（1990）にある「専門機関 のスタッフが保育所を訪問して、こどもの保育 所での生活を実際に見たうえで、それにそくし て専門的な援助活動を行うこと」という活動は、 現在多くの自治体の障害児保育に扔いて広く実 施されている。

浜谷直人ら（1990）障害児保育における専門 機関との連携一川崎市に招ける障害児保育巡 回相談のとりくみの視点と特徵——. 障害者問
題研究，60，42-52.

注 2 ：指導員とは学童保育クラブの職員であり、保育 を行う保育者である。相談員とは筆者らを含め た巡回相談の相談員を指す。

注 3 ：主訴とは、相談に際して指導員から事前に記述 される資料において、および巡回相談の現場に おいて出される、指導員の悩み・相談事項であ る。

\section{文献}

1）藤崎春代 - 西本絹子・浜谷直人・古屋喜美代・戸 田有一・吉川はる奈・村田叮子 (1992) 学童保育 クラブにおける障害児保育 (1)一自閉傾向のあ る坚童の場合一. 日本発達心理学会第 3 回大会 発表論文集, 150 .

2）浜谷直人・西本絹子・木原久美子・村田叮子・常 田秀子・藤崎春代・古屋喜美代・吉川はる奈・ 田口久美子・鈴木さ仂り (1994) 学童保育クラ ブ・保育園に扔ける統合保育 (3). 日本発達心 理学会第 5 回大会発表論文集, 256 .

3）伊藤三枝子 (1992) 目黒区の学童保育における障 害児保育. 障害者問題研究, 71, 223-228.

4）神山よしえ・森川鉄雄・小野あかね (1989) 自治体 の施策. 茂木俊彦・田中島苌 (編著)，学童保育 と障害児. 一声社, 94-158.

5) 宮武宏治 (1990) Ecological Psychology の視点か ら考察した重度・重複障害児のための教育課題 の設定. 特殊教育学研究, 28 (2), 43-55.

6）西本絹子・藤崎春代・浜谷直人・古屋喜美代・戸 田有一・吉川はる奈・村田叮子 (1992) 学童保育 クラブにおける障害児保育 (2)一軽・中度の精神 発達遅滞児の場合一. 日本発達心理学会第 3 回 大会発表論文集, 151 .

- 1994.4.1. 受稿, 1995.1.28. 受理 - 